\title{
LIBRARY SERVICES AMIDST COVID-19 PANDEMIC: ADJUSTING TO THE NEW NORMAL
}

\author{
Medinat Dolapo, LAARO \\ Kwara State College of Arabic and Islamic Legal Studies, Ilorin, Nigeria, \\ laaromedinat@yahoo.com
}

Manuscript Info Abstract

\section{Manuscript History}

Received: 15 December 2020

Final Accepted: 22 January 2021

Published: 10 February 2021

Online Published: March 2021

DOI: http://dx.doi.org/10.35337/EIJLITR.2021.1304

(c) Medinat Dolapo, LAARO The Author. This is an open access article under the terms of the Creative Commons Attribution License 4.0, which allows use, distribution and reproduction in any medium, provided the original work is properly cited.

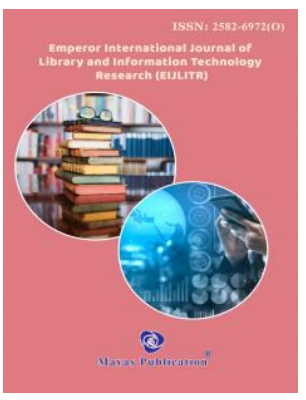

The incidence of COVID-19 pandemic impacted greatly on library services, their mode of operations and job ethics. The pandemic pushes for transformation of traditional library services into digital information services and as such, library work pattern that adhere to the COVID19 laid down protocols. This paper discusses library services during COVID-19 pandemic as well as how libraries can adjust to the new normal. It was concluded that libraries need to adopt a new system of library services that would improve their visibility on the web or cyberspace. Recommendations were given that library staff should be train and retrain on new technological tools for effective information dissemination in an online environment, measures must be put in place that guaranty the safety of library staff and users. Links to reliable information sources should be provided on the library website.

Keywords: Coronavirus (COVID-19), Library Services, Pandemic, Social Distancing, The New Normal.

\section{INTRODUCTION}

COVID-19 is an infectious respiratory disease caused by a new strain of family of coronavirus, with symptoms such as fever, cough, tiredness, muscle pain, loss of smell and in most severe cases breathing difficulty. It was first identified in December 2019 in Wuhan, China (Zhu, Zhang, Wang, Li, Yang \& Song, 2020). The virus is a communicable disease that spread through droplet from an infected person's exhale, cough, and sneeze. Droplets that drop on surfaces are contagious when touch by someone, who later used same hand to touch his/her nose, mouth or eyes. Centers for Diseases Control and Prevention (CDC, 2020) has once said that coronavirus (COVID-19) mainly spread when there is a close contact with effected person, but in October, 2020, it has been confirmed that it is also airborne. The transmission may also occur through aerosols that can stay suspended in the air for longer periods of time in enclosed spaces. It is most contagious during the first three days after the onset of symptoms, although spread is possible before symptoms appear, and from people who are asymptomatic. The incubation period of the virus is typically around five days but may range from two to fourteen days. Complications may include 
pneumonia and acute respiratory distress syndrome. Recommended preventive measures include hand washing, covering one's mouth when coughing, social distancing, wearing a face mask in public, disinfecting surfaces, ventilating and air-filtering, and monitoring and self-isolation for people who suspect they may be infected. Authorities worldwide have responded by implementing travel restrictions, lockdowns, workplace hazard controls, and facility closures to slow the spread of the disease. Many places have also worked to increase testing capacity and trace contacts of the infected. The World Health Organization declared the outbreak a public health emergency of international concern on 30 January 2020 and a pandemic on 11 March. As at the time of this review, there are over 80 million confirmed cases of coronavirus resulting in more than 1.5 million deaths and more than 42 million people recovered in more than 220 countries and territories (Worldometer, 2020). The impact of COVID-19 pandemic was not just only on health and the economy, its impact is also felt on the education sector where most schools have to transmit to online classes. Libraries, being an integer part of education system are partially closed and work pattern have to change to adhere to the lockdown restrictions. At some point, most library staff has to start working from home. A limited number of library staffs go to work onsite and provide limited services while non-essential staffs are working from home. The library is open with hours different from its normal schedule before the pandemic. Because libraries play such a vital role in keeping their patrons educated, connected, and entertained, librarians worldwide have been working around the clock to find ways to keep services going despite being closed to the public (Ali \& Gatiti, 2020). The pandemic made more evidence of challenges that have not been resolved in libraries. The major effect on library services is in the area of information service access and delivery beyond the four wall of the library. Also more evident is the digital divide and social exclusion of less urban and rural area due to absent of adequate information infrastructure to aid digital information services. COVID-19 pandemic has made it necessary for most library services to migrate to an online environment where physical contact between librarians and users would not be necessary (Onifade, 2020). Correspondingly, this is the new normal, where libraries need to adjust.

\section{Library Services during COVID-19 Pandemic: Adjusting to the New Normal}

COVID-19 pandemic had a great impact on libraries, which led to their initial closure. During the closure, they are forced to shift to remote operation and virtual information services using various communication tools (chat, audio or video conferencing) on social media such as WhatsApp, Facebook, Instagram, Webinar, Zoom, Google meeting, Microsoft team and many more to meeting the core needs of library users during the lockdown. All of this is to device alternative and active communication strategy that provide users with actionable information such as where to seek help in case of familiar symptoms of COVID-19 as well as safety measures to be taken. The pandemic pushes for transformation of libraries and a new vision of services that focus on building new relationship with users (Tammaro, 2020).

Now that libraries are re-opening in phases approach, first with library management staff and essential staff, the re-opening is still limited by the need for social distancing. There are important guidelines adopted in managing library staff and user's safety. Libraries are now inculcate policies for social distancing in the library, by reducing chairs in the reading space or probably reducing intake of users at a time to a barest minimum. Furniture are arranged to adhere to 6 feet social distancing recommendation of World Health Organization (WHO, 2020). Provision is made for separate entrance and exit in the library. Safe queuing spaces are maintained outside the library by demarcating 6 feet or 1.5 meters distance on the ground. Staff and users not feeling well most especially those with COVID-19 symptoms are not allowed in the library. Safe handling of library materials and facilities are ensured through sanitation of library surfaces, objects, users and library staff. Used library materials are quarantine and sanitized before recirculation (Australian Library and Information Association, 2020). 
Library re-opening did not translate to going back to the old ways of doing things same way they were before COVID-19 pandemic, but what it really mean is putting in place the new normal approach to library services. There would be a need for library to guaranty the safety of staff and users and also focus on safe handling of library resources and facilities. Moreover, now that users are accustomed with online information services, will they return to traditional library services? Hence, there is a need for strategy aim at transforming library with innovative version of information services. It will be up to the library administrators, as advised by appropriate authorities, prevalence of community transmission of COVID19 to determine when the library is safe for reopening.

\section{CONCLUSION}

Libraries are playing an important role in increasing public awareness of coronavirus (COVID-19) by disseminating information relating to preventive measures as well as providing research support for clinical and medical staff and researchers. They were saddle with responsibility of providing evidencebased information on COVID-19. Prior to COVID-19 pandemic, most libraries, most especially those established in developing and underdeveloped countries provide traditional library services with slight extension to digital/virtual reference services. Nevertheless, with the pandemic and subsequent lockdown imposed, inefficiency of traditional library services to continue to serve users at best was exposed. Aside the impact of the pandemic on library services, today Google generation set of users are millennial, web centric and technology savvy. They have become technology mastery, and as such always soughing instant information via ubiquitous computing that allow the use of technology devices and applications to access information remotely in any format and location. This has given rise to the need for libraries to adopt a new system of library services that would improve their visibility on the web or cyberspace.

\section{Recommendations}

Based on literature reviewed above, the following recommendations were given thus:

$>$ On effectiveness of librarians to be able to deliver dynamic information services to user during pandemic and post-pandemic period, recommendation is that they should be regularly trained on current trends and new technological tools for management and dissemination of information.

$>$ Libraries should made available social amenities needed to prevent the spread of the Coronaviruses such hand sanitizer, water and soap for users to wash their hands.

$>$ They should certainly ensure library materials and surfaces are cleaned before and after use.

$>$ Libraries should provide pages with useful links to reliable information for users on their websites.

$>$ Library staff and users should be encourage to used face mask and as well adhere to other COVID19 protocols when using the library and thereafter.

$>$ Libraries should implement plans to offer remote services, e.g. e-Lending, e-Learning, as well as providing support for remote teaching.

\section{REFERENCE}

1. Ali, M.Y. \& Gatiti, P. (2020). The COVID 19 (coronavirus) pandemic: Reflections on the roles of librarians and information professionals. Health Information and Libraries Journal, 37(2), 158162. Retrieved from: https://doi.org/10.1111/hir.12307

2. ALIA (2020). Australian libraries responding to COVID 19: Checklist for reopening libraries. Retrieved from: https://www.alia.org.au/sites/default/files/Reopening\%20Libraries.pdf

3. CDC (2020). Scientific brief: SARS-CoV-2 and potential airborne transmission. Retrieved from: https://www.cdc.gov/coronavirus/2019-ncov/more/scientific-brief-sars-cov-2.html

4. James, F., Chidozie, O. \& Chukwuma, L.N. (2020). Social media and library services: A case of COVID-19 pandemic era. International Journal of Research and Review, 7(10), 230-237. Retrieved from: https://www.ijrrjournal.com/IJRR_Vol.7_Issue.10_Oct2020/IJRR0031.pdf

5. Onifade, F.N. (2020). Library services during COVID-19 period: Federal University of Agriculture, Abeokuta experience. International Information and Library Review. Retrieved from: https://doi.org/10.1080/10572317.2020.1834247

6. Tammaro, A.M. (2020). COVID 19 and libraries in Italy. International Information and Library Review, 52(3), 216-220. Retrieved from: https://doi.org/10.1080/10572317.2020.1785172 
7. World health Organization (2020). Novel coronavirus. Retrieved from: https://www.who.int/bulletin/online_first/COVID-19/en/

8. Worldometer (2020). Coronavirus cases. Retrieved from: www.worldometers.info/coronavirus/?

9. Zhu, N., Zhang, D., Wang, W., Li, X., Yang, B. \& Song, J. (2020). Arrival of coronavirus from patients with pneumonia in China, 2019. The New England Journal of Medicine, 382, 727-733. Retrieved from: https://doi.org/10.1056/nejmoa2001017 